\title{
US Congress looks set to scuttle international fusion project
}

[WASHINGTON] The US Congress is poised to pass legislation seeking an end to US participation in the International Thermonuclear Experimental Reactor (ITER). The move is likely to lead to the collapse of a 13-year global effort to design and build a prototype fusion reactor.

The agreement to design ITER, intended to demonstrate sustained fusion in a magnetically confined plasma, expired on 21 July. Japan is said to feel that a three-year extension is contingent on the participation of all four parties - the United States, Russia, the European Union and Japan.

Russia's political interest is liable to wane if the United States withdraws. Officials say that the collaboration will therefore lie in ruins if, as seems likely, Congress passes an appropriations bill next month which pointedly advises the US Department of Energy to withdraw from the project.

Even if this were to happen, however, there remains a possibility that Europe might decide to build a new fusion reactor either on its own, as it was planning before the ITER project was agreed on, or in a separate collaboration with Japan.

Energy department officials, backed by the US magnetic fusion research community, have been imploring members of the House energy and water appropriations subcommittee to withdraw the advice they inserted in their proposed 1999 appropriations bill.

The officials want the DoE to be allowed to sign the agreement, even if it cannot spend any money on ITER. They say this would at least allow the other partners, each of which has signed the extension agreement, to proceed. "We need to be able to sign, regardless of the money," says Anne Davies, head of the magnetic fusion programme at the DoE.

Joseph McDade (Republican, Pennsylvania), chair of the energy and water appropriations subcommittee, believes that several questions about ITER need a better answer before the agreement is extended. According to a letter which he sent to Federico Peña, then the energy secretary, on 11 June, these include questions about "whether this construction project will ever be started".

Last week, the energy and water appropriations subcommittees of both the House and the Senate were close to holding a conference at which, officials say, the language advising the DoE not to sign would have been confirmed. But they didn't get round to it before the Senate recessed on 31 July. This gives the ITER agreement a breathing space until their return in September, when a final

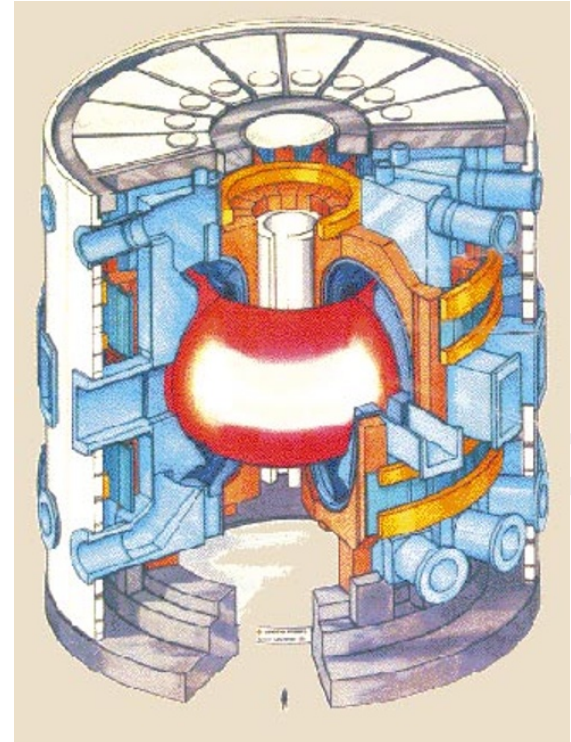

Looking into ITER: this may be all we ever see of it, if the United States backs out.

version of the appropriations bill must be agreed and passed into law.

James Sensenbrenner (Republican, Wisconsin), chairman of the House Science Committee, is to fly to Tokyo on 9 August to talk to senior Japanese officials about fusion research and other fields of US-Japanese research collaboration. Some officials and fusion scientists see this visit as a possible rescue mission for US participation in ITER.

In the cases of the International Space Station and the Large Hadron Collider, they note, Sensenbrenner has enjoyed making international visits in which he has noisily banged the drum for American interests, scolded the Clinton administration for its alleged failure to protect these interests and then strongly supported both projects.

But sources close to the Wisconsin congressman are playing down such expectations in the case of ITER. During the five day trip, they say, he will try to soothe what are expected to be bruised Japanese feelings over the possible demise of the ITER agreement, find out if Japan is serious about a scaled down, incremental version of ITER, and look at possibilities for fusion research collaboration outside of ITER.

Although it is McDade - not Sensenbrenner - who is ready to kill the agreement, officials are nonetheless pinning their hopes on the latter. Asked if his trip could help save the agreement, Davies says: "I certainly hope so."

The last ITER Council meeting in Vienna amply demonstrated the fragile status of agreement. After meeting on 21 July - the date on which the six-year agreement to conduct an engineering design assessment of ITER expired - Japanese officials contended that the legal basis for the council had expired, as its terms require all four parties to agree on the proposed three-year extension.

The officials at Vienna then met informally on 22 July and agreed to keep talking informally until October, by which time the US situation should be resolved.

ITER research in the United States is continuing, at least until the end of the financial year on 30 September. "In terms of the tech-

\section{Retailer appointed UK minister for science}

[LONDON] Lord Sainsbury, former chairman and chief executive of the large chain of supermarkets that bears his family's name, has been named as Britain's new science minister following a cabinet reshuffle last week.

Tony Blair, the prime minister, also announced that Sir Robert May, the government's chief scientist, will be given an office in the Cabinet Office, a move frequently demanded by critics since the Office of Science and Technology was moved to the Department of Trade and Industry (DTI) in 1995 (see Nature 376, 103; 1995).

Sainsbury was named last week as a new minister in the DTI, where he will serve under Peter Mandelson, a leading architect of the Labour Party's victory in last year's general election. He takes over the science portfolio from John Battle, who retains his other responsibilities, including energy issues. Mandelson becomes the cabinet minister responsible for science and technology.

Sainsbury has long been an active promoter of scientific and technological causes, ranging from school education to support for research in plant pathology, through the activities of the Gatsby Foundation, the charitable trust on which he has settled much of his personal wealth.

The foundation's capital assets are said to

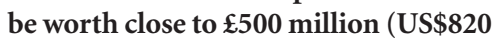
million). Projects it has backed include the creation of a plant research laboratory at the John Innes Centre in Norwich, and a unit for cognitive neuroscience at University College London.
David Dickson 
nical work we are continuing with business as usual," says Charles Baker, head of the US ITER team based in San Diego, California.

But a senior scientist at one US fusion facility describes the situation as "a shambles", while Baker admits: "Of course we are very concerned about the future".

Despite the uncertainty, a "special working group" of 20 scientists from the four partners is pressing on with two tasks assigned to them by the ITER council. The first, which is more or less complete, determined that a smaller version of ITER known as 'ITER-Lite' - costing $\$ 5.5$ billion instead of $\$ 10$ billion, could meet many of the project's technical objectives (see Nature 393, 406; 1998).

The second task, requiring the group to explore other collaborative experiments short of that, is proving more difficult to execute. At Vienna, the United States pushed for the group to formally spell out such options. But ITER advocates in Europe and Japan fear that such a step will undermine the case for any version of ITER.

For many of its supporters, ITER's symbolism as an example of international collaboration in science is at least as important as its technical objectives. It is on the basis of that broader significance that the energy department is now trying to save the agreement in the Congress.

President Bill Clinton will not, however, veto the energy and water appropriations bill in order to save the agreement. And its fate is likely to have little impact on support for the US magnetic fusion research programme, which will be funded next year at close to this year's level of \$229 million. ColinMacilwain

\section{Fall in Australian R\&D is linked to tax law change}

[SYDNEY] After 11 years of sustained growth, business expenditure on research and development has fallen sharply in Australia, according to two independent surveys by business and government.

The fall is being linked to the coalition government's cut in a tax concession for research and development in industry, from 150 to 125 per cent, two years ago. At the time, the government claimed it was needed to correct alleged - though never proved - abuses of the system through 'creative accounting' by some claimants.

An analysis by the Business Council of Australia (BCA) concludes that the concession was a "super-efficient vehicle for encouraging business expenditure on research and development, as business decision-makers tend to overestimate the benefits to their company's shareholders".

The BCA calculates that more than A $\$ 1.5$ billion (US $\$ 908$ million) in research and development has been lost since 1996 by 150 businesses with a total turnover of A $\$ 125$ billion; this is about one-third of the expenditure predicted if the concession had remained at the higher level. A survey by the Australian Bureau of Statistics agrees with the BCA, claiming that business investment in research declined by 7 to 8 per cent in real terms in the first year after the cut (1996-97).

The tax incentive was introduced in
1985 by a Labor government, at a rate competitive with Asian nations such as Singapore and Malaysia, to boost Australia's low level of industrial research and development. The move was followed by an immediate increase in business investment in research.

Over the five years to 1995, business investment grew by 13 per cent a year in real terms, rising from 0.5 per cent to 0.8 per cent of gross domestic product. An industry spokesman for the opposition Labor Party, Simon Crean, says the government will have cut $\$ 2$ billion in incentives for research and development over the four years to 2000 .

He accuses prime minister John Howard of leaving Australian industry "severely exposed in an increasingly competitive international environment". Australia's federal science minister, John Moore, has announced amendments aimed at "streamlining" the tax concession and has agreed to the BCA's call for a "summit" on business research and development next year.

The BCA reports that the hardest hit areas are in "the more strategic and speculative research and development". It says that nearly a third of business investment was in "research-intensive sectors, including pharmaceutical and biomedical manufacturing, electrical goods manufacturing and telecommunications". Peter Pockley

\section{Japan picks prominent physicist to lead education ministry}

[токуо] Physicist Akito Arima, a former president of Tokyo University and an influential voice in recent debates on how Japan should manage its science, was last week appointed education minister in the cabinet of Keizo Obuchi, Japan's new prime minister.

His appointment as head of the Ministry of Education, Science, Sports and Culture (Monbusho) has raised hopes about the chances of much-needed reforms to the country's universities and changes in the way science is managed.

Arima's appointment was announced on 30 July, two weeks after he was elected to the Upper House of the Diet (Japan's parliament) as the top candidate of the proportional representation list of the ruling Liberal Democratic Party (LDP); this allocates seats to candidates according to the number of votes polled by the party.

Until May, 67-year-old Arima was president of the Institute of Physical and Chemical Research (RIKEN), the renowned

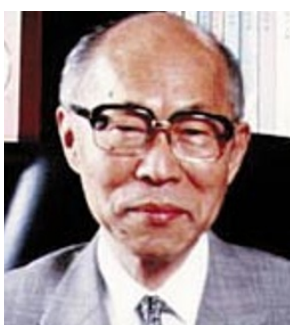

Arima: an outspoken supporter of science. research institute overseen by the Science and Technology Agency (STA).

Arima has been a member of various government panels, including the councils for central education and administrative reform. Given this background and the LDP's strong support for him during the election, his appointment is not surprising.

His supporters included the former prime minister Ryutaro Hashimoto, who resigned after his party's poor showing at the polls, and whose administrative reform plans Arima helped draw up last year. Hashimoto belongs to the same political faction in the LDP as Obuchi.

Arima has long been an outspoken supporter of Japanese science and a key advocate of reforms in its organization. For example, he was responsible for introducing the first external reviews of a Japanese university, and helped to shape the 1996 Basic Law for Science and Technology which was designed to increase Japan's spending by 50 per cent by the year 2001.

His appointment is seen as increasing the chances of success of the impending merger between STA and Monbusho. Many researchers have been concerned about the merger, claiming that STA's 'top-down' approach and Monbusho's educationorientated 'bottom-up' approach to research are fundamentally incompatible (see Nature 390, 327; 1998) .

Scientists generally support Obuchi's choice of Arima, but many are concerned that the new cabinet may not last long. The latest public opinion poll conducted by Asahi Shimbun shows that there is only 32 per cent support for Obuchi, so Arima may lose the chance to make a significant impact during his term of office. Asako Saegusa 